\title{
HISTORICAL METHOD AND EARLY HEBREW TRADITION ${ }^{1}$
}

\author{
By K. A. KITCHEN
}

One of the most enlivening and valuable features of Near Eastern historical studies during these last four or five years has been the regular appearance of successive fascicules of the new edition of the first two volumes of the Cambridge Ancient History. With well over 40 fascicules published or in the press, perhaps a half of the whole is now (or soon will be) available. From the Aegean to Mesopotamia and Elam; from the austere Anatolian uplands across the Syrian littoral to the ribbons of culture along the Nile, we are treated to a richly documented series of essays that mark in a myriad of ways the vast strides in our knowledge and understanding of the Ancient Near East in the four decades which have elapsed since the first edition of $C A H, \mathrm{I} / \mathrm{II}$ appeared in 1924-26. Suffice it to mention the brilliant discoveries at Ugarit, Mari and its archives of 20,000 tablets, the systematization and extension of an entire province of archaeology in Anatolia, the dramatic recovery of remarkable Neolithic and later cultures there and in Syria-Palestine and Mesopotamia, and the steady advances in our knowledge of the two 'senior' civilizations of Mesopotamia and Egypt.

Both in the old $C A H$ and in the new one, among the records of the politically 'lesser' peoples, the Hebrew traditions of the Old Testament have their due place. For the new $C A H$ I/II, Professor Otto Eissfeldt, well known in continental Old Testament studies, has written two fascicules.

I. A paper arising from O. Eissfeldt, Palestine in the Time of the Nineteenth Dynasty, (a) The Exodus and Wanderings, and The Hebrew Kingdom, being chapters 26(a) and 34 of the revised volume II of the Cambridge Ancient History, Cambridge University Press (1965). These fascicules and the History will be referred to as Exodus . . ., Hebrew Kingdom, and CAH. 
In the first (The Exodus and Wanderings), he briefly comments on the limited sources of information for Old Testament characters (i.e., usually the Old Testament alone), and upon the supposed literary structure of the Pentateuch. Then he considers the Hebrew patriarchs-who or what they were, their possible date, the role of their need of pasture in relation to traditions of early Hebrew movements in and out of Egypt. Eissfeldt next deals similarly with the traditions of the Exodus and the wanderings in Sinai and Transjordan. In the second fascicule (The Hebrew Kingdom), like consideration is given to the settlement in Canaan and the period of the Judges, before passing on to the generally acknowledged solid ground of the reigns of Saul, David and Solomon.

In that second fascicule, we find - to use Eissfeldt's words (6) a 'positive form [of historical treatment that] intentionally avoids' the kind of 'resigned scepticism' of $C A H$, first edition, when we read the sections (VII-IX) on Saul, David and Solomon; that on Canaan and Israel (VI) is likewise 'positive' and notable for its appropriate use of external comparative material. One receives the impression of regular historical method, applying external (hence relatively objective) data for the elucidation and evaluation of the available sources.

However, in the first fascicule (Exodus ....) and sections $\mathrm{I}-\mathrm{V}$ of the second, this is not so. Instead, we are presented with what is, in fact, an able summary of a maze of speculation, but not.with history in any normal sense, while the contribution of external controls has been almost entirely dispensed with. Here, one may beg leave to doubt whether it is possible to register any fundamental advance since $1924-26$ in the picture drawn by Eissfeldt. Such observations, however, have a bearing on Old Testament studies far beyond these fascicules.

The general criticisms in the last paragraph may best be exemplified by reviewing in outline some aspects of early Hebrew tradition (particularly the patriarchs)-the sources (internal and external), nature and historical or other status of the patriarchal figures, the possible date of the patriarchs, some arbitrary and erroneous procedures adopted by Eissfeldt, and some other brief points. 
As Eissfeldt well states (Exodus ..., 3 (cf. 9) I7), the Old Testament is our sole source of explicit information about the patriarchs and the Exodus, i.e. the only source that actually mentions them. However, this basic fact has certain consequences: in so far as the particular picture of the patriarchs and the Exodus presented in the Old Testament is the sole account that antiquity itself has bequeathed to us, we have no independent second account by which to judge objectively the reliability or even the essential nature of that sole extant picture. Now if we proceed to reinterpret the one available account so drastically as to produce a different picture (or simply replace that account by a modern hypothetical reconstruction), then we have in fact removed our sole body of inherited positive evidence on the patriarchs, etc., ${ }^{2}$ and have replaced it with something that is by nature pure guesswork. ${ }^{3}$ Unless clear evidence of a tangible kind can be brought forward in its support, such guesswork cannot be verified; it then remains in the realm of pure theory, has no advantage over the Old Testament account, and has no place in a serious history.

\section{$B$ External}

However, there is available a variety of external information from the Ancient Near East-the world of the Old Testament and its characters-which can be compared with the Old Testament data. The degree of relevance (and hence the role) of the external data is a question of crucial importance. One

2. Regardless of what historical value be placed on that evidencewhether treated as exact history throughout, or a purely legendary reflection of later times, or anything in between.

3. No matter how brilliant, or finely adorned with all the critical acumen of scholarly judgment, guesswork remains qualitatively guesswork, from the point of view of a strict and proper methodology.

4. History, particularly in relation to a project such as $C A H$, is here taken in its common and perfectly well understood meaning of 'what has actually happened' at any time prior to the present, with particular reference to the activities and vicissitudes of mankind. Any account of the past is, and must be, highly selective; but this has no relevance to the reality of people having lived and events having actually occurred.

C 
limitation of such data is already apparent: the rarity of direct mention of Old Testament figures.

Actual mentions in external sources principally concern the kings of Judah and Israel from the ninth century BC onwards. They occur in Assyro-Babylonian records solely because as local heads of state they came into conflict with, or vassalage under, Assyrian or Neo-Babylonian rule; the Mesopotamian royal annals and chronicles had almost no occasion to mention any other Hebrews by name. Before the ninth century, Assyrian power did not reach into Palestine, and so its official records do not mention the Hebrews. From Aram of Zobah and Damascus, hardly any first-hand written documents have been recovered; apart from a few very incomplete records of Shoshenq I (Shishak), Egyptian sources on Syria-Palestine after Ramesses III (whose texts leave much to be desired), i.e. c. $1200-600 \mathrm{BC}$ in very round figures, are practically nil, presumably mainly lost. Only in Palestine could one reasonably expect many documents mentioning non-royal Old Testament characters (if they had occasion to appear in writing); but practically all such documents-ostraca, papyri, stelae-have long since perished. They once did exist; witness the Samaria and Lachish ostraca, Siloam inscriptions, and Moabite stone, also the impressions of papyri on sealings of Gedaliah from Lachish, ${ }^{5}$ all eloquent of what has been lost. In Egypt and Mesopotamia, conditions have been more favourable for the survival of stone and of papyri and clay tablets respectively (though losses have been enormous) and so these lands have yielded far more written data. Thus, Near Eastern documents currently available do not actually mention (e.g.) the Abraham, Isaac or Jacob of Genesis I I-50, and so cannot explicitly prove at present ${ }^{6}$ that these figures

5. E.g., G. E. Wright, Biblical Archaeology, Duckworth, London (1957) 178 and fig. 128.

6. As do the Neo-Babylonian ration-tablets for King Jehoiachin of Judah, for example (E. F. Weidner, Mélanges Dussaud, II, Geuthner, Paris (1939) 923-935; $f$. latterly, A. L. Oppenheim in J. B. Pritchard (ed.), ANET, Princeton University Press (1950/55) 308, or W. J. Martin in D. W. Thomas (ed.), DOTT, Nelson, London (1958) 84-86). 
were flesh-and-blood people like ourselves, who once actually lived on this earth.

This is true, but is not the whole truth. 'Negative evidence' or the mere non-mention of a person or event in contemporary (or relevant later) documents ( $I$ ) is not peculiar to the patriarchs or the Exodus and (2) in itself proves nothing at all about the figures concerned. Apud (I), we have as yet no external mention to vouch for such figures as David or Solomon; but no-one today would dream of using that fact to demonstrate that either David or Solomon were purely fictitious, or other than individuals, each in his time a king of Israel and Judah. The lack of a direct, external 'proof' (2) merely illustrates the sober fact of vast, yawning gaps in our surviving available ancient documents. So much remains to be discovered; so much more has irrevocably perished long since. ${ }^{7}$ Thus, 'negative evidence' can prove nothing about the patriarchs, Exodus or other early traditions. If we decide to substitute some modern theoretical picture for the existing Old Testament account, then we must have tangible reasons for so doing; mere non-mention of people, events, etc., externally does not constitute such evidence.

While the Near Eastern comparative data at present available do not, then, prove Abraham's former physical existence or individuality by any direct mention, yet such material is relevant to the patriarchal and other early traditions in other ways. The existence of this material is acknowledged by Eissfeldt (Exodus . . ., 3, 9, I7, etc.), but he insists that such data 'should not be used as a guide in any attempt to answer the complex questions posed by the biblical account' (3), because he considers the material to be 'so ambiguous' (3), and 'much too open to various interpretations' (9), as far as

7. Perhaps as much as 99 per cent of cuneiform documents remain to be found, and a like proportion of Near Eastern mounds remain undug; cf. E. Chiera, They Wrote on Clay, Chicago University Press (1938) 233, and G. H. Gordon, Adventures in the Nearest East, Phoenix House, London (1957) 13, among others. Vast quantities of papyri and stone inscriptions have long ago perished in Egypt, $c f$. G. Posener, Collège de France (Chaire de Philologie et Archéologie Egyptiennes), Leģon Inaugurale, 6 Dec. 1961, Collège de France, Paris (1962). 
the patriarchs are concerned. On these grounds, he refuses in practice to allow the external data to have any bearing on his evaluation of the patriarchal figures of Genesis.

Now, if the external comparative data are as ambiguous as Eissfeldt has claimed, then his apparent caution (as quoted just above) would be wholly commendable. But the plain fact of the matter is that a good amount of this material is not so ambiguous as Eissfeldt would have us believe; consequently, it does have some bearing on the questions from which he would exclude it. Let us look briefly at some of this material.

\section{(a) Proper Names}

r. Names of Relation, e.g. Ab-ra(ha)m and Ben-jamin. In the ancient Semitic languages such names are exceedingly common, ${ }^{8}$ not least among the West-Semitic names of the first half of the second millennium BG. ${ }^{9}$ Such names are personal names of individuals ${ }^{10}$-almost never of deities or tribal groups. ${ }^{11}$

2. 'Amorite Imperfective' Names, ${ }^{12}$ e.g. Isaac ( ișhaq), Jacob $\left(Y a^{6} q o b\right) /$ Israel (Yiśra'el); Ishmael (Yisma's'el), Joseph (Yösep). This type of name is exceedingly common for the personal names of human individuals among Western Semites in the early

8. For Akkadian, cf. (e.g.) K. Tallqvist, Assyrian Personal Names, Helsinki (IgI8) 4f., 263 (Abi); or I. J. Gelb, P. M. Purves, A. A. MacRae, Nuzi Personal Names, Chicago University Press (1943) 290, 305 (Abu/i), 308 (maru, 'son'); J. J. Stamm, Akkadische Namengebung, Hinrichs, Leipzig (1939) 37ff. (maru, binu, aplu), 53ff. (abu). For Ugaritic, $c f$. G. H. Gordon, Ugaritic Manual, III, Pontifical Biblical Institute, Rome (1955) 231, No. 5 (or now his Ugaritic Textbook, same publisher (1965) 348, No. 8) for $a b$-names; for scores of $b n$ - names, $c f$. G. D. Young, Concordance of Ugaritic, Pontifical Biblical Institute, Rome (I956) 12-I 7, and G. Virolleaud, $P R U, \mathrm{~V}$ (1965) I55ff. and 203 passim.

9. In Mari, $c f$. H. B. Huffmon, Amorite Personal Names in the Mari Texts, Johns Hopkins Press, Baltimore (1965) I54 (abi/u), 120-12 1, 175-1 76 (binu).

10. So throughout the works just cited.

I I. A deity Mar-biti in Akkadian, cf. (e.g.) Tallqvist, Assyrian Personal Names, 127-1 28, 257-258. In tribal names like Mare-Yamina, MareSim'al, etc., the 'son' element is, of course, plural and not a singular as in 'Benjamin' or other Bn- personal names.

12. To use Huffmon's phraseology (op. cit. 63), slightly modified, for a purely conventional term. 
second millennium $\mathrm{BC}$ and sometimes later, ${ }^{13}$ not for deities or tribes. While 'Isaac' and 'Joseph' faithfully reflect this type in general, 'Ishmael', 'Jacob' and 'Israel' find direct counterparts in Yasmah-el/-Baal/-Dagan, ${ }^{14}$ in Yahqub-el, ${ }^{15} \mathrm{Ya}^{6}$ qob-har, ${ }^{16}$ and $Y_{i s} r^{\prime}-i l^{17}$ (thirteenth century ${ }^{B C}$ ) respectively, all but the last belonging to the Old Babylonian period, especially the Mari archives.

3. Other Names. For Levi, $c f$. personal names in Lawi-.18 For Zebulon, $c f$. Old-Babylonian Zabilanu and Execration Texts Zabilu-Hadda; Issachar, Dan, Gad and Asher likewise have their appropriate analogues among human personal names of the second millennium BC. $^{19}$ Some previously suggested links with divine names are fallacious. ${ }^{20}$ Animalnames, such as those borne by Hamor, or among the ladies as Leah and Rachel, are well-attested as personal names for individuals. $^{21}$ Other examples could be adduced, but these must suffice.

The foregoing material is certainly not ambiguous: all the more important patriarchal names fall consistently into the class of human personal names, not those of deities, tribes, etc.,

13. At Mari, cf. J. Bottéro and A. Finet, Archives Royales de Mari, XV, Imprimerie Nationale, Paris (1954) I45-I 47 passim, also Huffmon, op. cit. 37-49.

14. For examples, of. Huffmon, op. cit. 44, 249-250.

I5. Ibid. 203-204.

16. $C f$. latterly S. Yeivin, $\mathcal{Z} E A 45$ (1959) 16-18.

17. From Ugarit; $c f$. Virolleaud, $P R U$ V (1965) 97 No. 69:3.

18. $C f$. Huffmon, op. cit. 225-226.

19. References for these, $c f$. my Alter Orient und Altes Testament, Brockhaus, Wuppertal (1965) Anmerkungen 97-99; Huffmon, op. cit. 88, 183 (Dani-AN).

20. E.g., Asher ('blessed' or the like) has nothing to do with the goddess Ashirat (-yammi); cf. W. F. Albright, Archaeology and the Religion of Israel, ${ }^{3}$ Johns Hopkins Press, Baltimore (1953) 77-78, and my Ancient Orient and Old Testament, revised English ed. (forthcoming), under 'Early Hebrew Chronology', iii, (d),2, with references. Gad for 'fortune' as a deity seems not to be known in the early second millennium $\mathbf{B C}$, but is probably merely a later and secondary personification in the Semitic pantheon, and hence is irrelevant for a human Gad in the early second millennium $\mathbf{B C}$.

21. In Akkadian, $f f$. Stamm, Akkadische Namengebung, 253-255; Gelb, Purves, MacRae, Nuzi Personal Names, 292. In W. Semitic, $c f$. Huffmon, op. cit. I5 I-I 52 . 
and sometimes find literal equivalents. The patriarchal names speak unequivocally in favour of their bearers having been men and women, not deities or tribal groups.

\section{(b) Legal and Social Usages}

In Genesis 15:1-5, we see Abraham, childless, as having adopted a servant (Eliezer) as heir, the latter to be replaced eventually by a promised son.

Genesis 16:Iff. shows Sarah giving her handmaid Hagar to Abraham to bear him an heir (thus Ishmael) 'by proxy', so to speak.

Genesis I 7:I $5 \mathrm{ff}$. and 21:12 show Isaac (Abraham's son by his chief wife Sarah) supplanting the handmaid's son as heir. But in Genesis 21:roff., Abraham requires divine sanction before he feels able to expel the handmaid and her son. Just like Sarah, the childless Rachel gave her handmaid Bilhah to Jacob (Gn. 30:I-8), and Leah, after ceasing to bear, did likewise with Zilpah (Gn. 30:9-13).

These usages have been frequently compared with those seen in the Nuzi tablets, as Eissfeldt (Exodus . . . 9) is aware. ${ }^{22}$

Slaves were adopted ( $c f$. Eliezer). ${ }^{23}$ The adoptee would perform the requisite services for the adoptor(s) and become heir, taking second place if the adoptors then had offspring of their own ${ }^{24}$ ( $c f$. Ishmael and Isaac). Furthermore, Nuzi usage allowed explicitly for a childless wife ( $c f$. Sarah; Rachel, and for a time Leah) to provide her husband with a concubine (cf. Hagar; Bilhah, Zilpah) to bear children in her stead ( $c f$. Ishmael; Dan, Naphtali; Gad, Asher). Subsequent offspring of the chief wife ( $c f$. Isaac) would become chief heir(s), although the handmaid's offspring were not to be expelled ( $c f$. Abraham's

22. Fissfeldt's speculations about the womanly rivalries in Gn. 29-30 being poetic narrative invention ( $c f$. Hebrew Kingdom I4) are directly contradicted by the close correspondence here noted with the usage of real life in the first half of the second millennium (Nuzi and precursors), presupposing an ultimate origin of these -kinds of detail in that period. Names of good omen (like Gad, Asher) are well attested humanly, and are irrelevant to historicity.

23. See C. H. Gordon, $B A 3$ (1940) 2.

24. Ibid.; E. A. Speiser, $A A S O R$ 10 (1930) 30. 
reluctance in Gn. 21 :I0-I2). ${ }^{25}$ Moreover, such practices go back much earlier than Nuzi. ${ }^{26}$

Even from this brief summary, it should be crystal clear that the correspondence between the Nuzi, etc., usages and Genesis $(15-17,21,30)$ is not 'ambiguous' but remarkably exact. This is true of other details. A birthright might be sold both in Genesis (25:30-34) and at Nuzi (e.g., for three sheep). ${ }^{27}$ The details of Jacob's marital dealings with Laban (Gn. 29-3I) compare with Nuzi data, ${ }^{28}$ likewise the legal validity of oral blessings in Genesis $(27 ; 48: 9 f f . ; c f .49)$ finds a counterpart at Nuzi. ${ }^{29}$

Using different comparative data, the episode of Abraham's buying the cave of Machpelah and the land around it from Ephron the Hittite (Gn. 23) only recovers its full flavour when appropriately set against $\S \S 46,47$ of the Hittite Laws. ${ }^{30}$ In addition, it may be noted that the price of 20 shekels paid for Joseph (Gn. 37:28) corresponds to the average slave price of one-third of a mina (=20 shekels) in the early second millennium BG. ${ }^{31}$

Throughout, these are not vague or 'ambiguous' semblances, but close and precise correspondences that could hardly be bettered anywhere. Furthermore, the particular customs

25. All this is visible in tablets such as H.V.67 in Speiser, op. cit. $32 ;$ ff. Gordon, loc. cit. 3 .

26. Cf. the Lipit-Ishtar laws of nineteenth/eighteenth century BC, $\S 25$ (and 26), in J. B. Pritchard (ed.), ANET I6ob, on children of chief and slave wives; $\S 27$ on childless couples, with children of a subordinate union as heirs. With $\S 28, c f$. Leah and Rachel both kept by Jacob (not divorcing Leah). With $\S 26$ where a first wife's children remain heirs after the husband (widower) has remarried and has further children, $c f$. Abraham in Gn. 25:1-6.

27. Gordon, loc. cit. 5 .

28. E.g., ibid. 5-7; but for the teraphim see now M. Greenberg, $\mathcal{F B L} 8 \mathrm{I}$ (I962) 239-248.

29. Gordon, loc. cit. 8.

30. M. R. Lehmann, BASOR 129 (1953) 15-18, an important study omitted from Eissfeldt's bibliography. Comparisons with dialoguedocuments by $\mathrm{H}$. Petschow, $\mathcal{F} C S$ ig (1965) 103-120, and G. M. Tucker, $\mathcal{F B L} 85$ (1966) 77-84, miss the real point; of. my Ancient Orient and Old Testament, Section B.r,i,b.

31. References, Kitchen in F. F. Bruce, J. I. Packer, R. V. G. Tasker, D. J. Wiseman and J. D. Douglas (eds.), New Bible Dictionary, I.V.F., London (1962) I 195-I 196. 
shared by the patriarchs with documents of the first half of the second millennium do not feature as socially valid in later ages (e.g., in the 'laws of Moses', etc.), hence they could not simply 'have become known to the Israelites when they entered Palestine' at the conquest as Noth suggested. ${ }^{32}$

\section{(c) Other Aspects}

I. Religious. Two aspects of patriarchal religion as depicted in Genesis have been fittingly compared with external data: the concept of the God of the father(s) with its closest analogues in the early second millennium $\mathrm{BC}^{33}$ and the prominence of $\mathrm{El}$ (with varying epithets) as God of the patriarchs. ${ }^{\mathbf{3 4}}$

2. Geopolitical. Firstly, the coalitions of kings in Mesopotamia (Gn. I4) correspond perfectly with conditions in the Old Babylonian period until Hammurapi-not earlier under the IIIrd Dynasty of Ur, nor later from Hammurapi's brief dominance onwards. ${ }^{35}$ Secondly, the situation in Palestine in the patriarchal narratives-city-states like Shechem, Hebron, the Dead Sea towns, etc., and tribal groups in their hinterlands -is directly comparable with that discernible from Egyptian data of the Middle Kingdom. The Execration Texts show towns and city-states, sometimes with multiple rulers, and

32. History of Israel ${ }^{2}$, Black, London (1960) 84; nor are these usages necessarily solely Hurrian as he implies-cf. the comparative data from Ur and the Lipit-Ishtar laws.

33. See W. F. Albright, BASOR 163 (196r) 48-49, and F. M. Cross, $H T R 55$ ( 1962 ) 225-259; neither of these papers appears in Eissfeldt's bibliographies as we would have expected them to do.

34. In Ugaritic myths and epics of early to middle second millennium $\mathrm{BC}$, in copies of late second millennium $\mathrm{BC}, \mathrm{El}$ is tantamount to a 'has-been' as effective ruler of the gods; among the.W. Semites, his real supremacy is therefore to be placed not later than the early second millennium BC ( $c f$. M. Pope, El in the Ugaritic Texts, Brill, Leiden (1955) 27-35, 82-104 (103-104 for the patriarchs)).

35. In relation to patriarchal chronology (early second millennium), this was first clearly pointed out by me in Alter Orient und Altes Testament (I965) 2off. and Anmerkung 8o; revised edn., Ancient Orient and Old Testament (forthcoming), 'Early Hebrew Chronology', ii, (a), third point. 
'tribes' of the hinterlands, etc., a picture supported by the story of Sinuhe. ${ }^{36}$

3. Travel. Visits to Egypt by Palestinian chiefs (cf. Abraham and Jacob) are illustrated by the sheikh 'who had been to Egypt' (Sinuhe, B.26/R.50), and by Abishar leading a party of 37 Asiatics depicted in a well-known scene in a Beni Hasan tomb-painting. The escort given to Abraham to see him out of Egypt (Gn. 12:20) is a counterpart of that accorded to Sinuhe when returning to Egypt (B.245 and especially 248); both Abraham and Sinuhe were objects of particular (if differing) concern to the king in their respective stories. For the general scope of wide travel in the first half of the second millennium $\mathrm{BC}$, like the patriarchs ranging eventually from Ur to Harran and into Syria-Palestine with visits to Egypt, one need only mention the Mari archives showing diplomatic and commercial travel from Babylon as far west as Hazor, plus the incessant movements of semi-nomads in Mesopotamia, Upper Syria and beyond, and the Cappadocian tablets with their record of commerce and constant interchange between Assyria and Anatolia.

More detailed study of these and other points than can be included here would show little ambiguity; the conditions depicted in Genesis and the phenomena observable in the external documents correspond remarkably well. Some of the material is especially characteristic of the early second millennium $\mathrm{BC}$, some of it holds good over a much longer range of time.

\section{(d) Consequences}

In summary we may observe from the external sources relevan to the patriarchs that: (I) None of them as yet actually mention any of the Genesis patriarchs by name. (2) There is frequently precise correspondence in type (and sometimes in actual names) between patriarchal names and human personal names (as

36. In the patriarchal narratives, there is nothing to compare with Egyptian rule there during much of the sixteenth to mid-thirteenth centuries BC. Thereafter, with the conquest and settlement, conditions in Palestine became very different from earlier times, so that the patriarchal narratives cannot possibly reflect post-conquest conditions. 
opposed to tribal or divine), and in part particularly West Semitic names of the early second millennium BC. There is the closest correspondence in various legal and social usages affecting marriage, children and inheritance between patriarchal and Mesopotamian (especially Nuzi) customs, and considerable correspondence in other details. In a supposedly 'Hittite' episode (Gn. 23), it is appropriately the Hittite laws that give point to the Genesis story. In other aspects of patriarchal life (e.g., religion, travel, geopolitical background), a close and at times exact correspondence can be seen with the external data: paternal deity, role of $\mathrm{El}$ (who was otiose later); wide travel, Semites visiting Egypt; Mesopotamian coalitions (characteristic for the Old Babylonian epoch); city-states and tribes in Palestine, etc.

To describe the foregoing material-much of it quite well known-as 'so ambiguous' and 'much too open to various interpretations' is not only unduly pessimistic, it is positively misleading. While it is perfectly true that different scholars may choose to put widely differing interpretations upon such data, yet the actual correspondences (however regarded) are perfectly plain; Eissfeldt's quoted judgment simply does not do justice to that fact.

II. NATURE OF THE PATRIARGHAL FIGURES AND QUESTION OF HISTORICITY

\section{A Nature}

As late as 1965, Professor Eissfeldt still felt it necessary to debate actively whether the patriarchs of Genesis are to be taken as individuals, as personifications of tribes, as tribal groups, or as former Canaanite deities or heroes (Exodus . . . $5^{-6)}$. Had he referred this debate to the past history of interpretation, no objection could possibly be raised; but he evidently regards it as still open. However, if regular historical method (as used in the rest of Near Eastern studies) is to be applied rather than ignored, this question of the nature (as opposed to the historicity) of the patriarchs must be considered as already closed. It can be reasonably stated that the patriarchs 
were individuals, not personifications, tribes, or former deities and heroes. ${ }^{37}$ Whether they were real or imaginary individuals is a separate question ( $c f$. below, pp. 77-82).

Why may one so confidently consider the question closed? Simply because the evidence available clearly indicates individuals, and as clearly speaks against the other theoretical possibilities.

I. The idea of old Canaanite deities is ruled out by both the internal and external data. Genesis itself frequently shows the patriarchs as religious men, worshipping $\operatorname{God}^{38}$ and not themselves receiving divine honours. ${ }^{39}$ The external data cited above show that the names of the patriarchs are of kinds current among men and women, particularly West Semitic and in the early second millennium $\mathrm{BC}$-not as the names of Canaanite or other deities. The last serious attempt to the contrary was based on a misunderstanding of the Ugaritic epics, and crashed to disastrous ruin. ${ }^{40}$

2. The concept of the patriarchs as being tribal groups or personifications of tribes ${ }^{41}$ can also be ruled out. ${ }^{42}$ Genesis itself clearly depicts them as individuals who are born into a family, who marry, have children, die of old age and are buried. The wanderings, alliances (including matrimonial)

37. M. Noth, History of Israel ${ }^{2}$ (1960) 1 22-123 and n.2, would admit this much.

38. E.g., building altars and praying (Gn. $12: 7,8 ; 22 ; 28: 18 ; 33: 20$; $35: 1-7,14)$; taking oaths and vows (Gn. $14: 22 ; 28: 20-22 ; 31: 53-54)$; practising circumcision-what god was ever circumcised? (Gn. I7: gff.).

39. As R. de Vaux pointed out long since, the supposed shrines (Hebron, Beersheba, etc.) of which the patriarchs would have been deities or heroes lack all independent substantiation ( $f . R B$. 53 (1946) 322-333); and their sites are wholly different from the Israelite sacred sites of the Monarchy period to which such as Eissfeldt would date these stories (cf. ibid. 325); Eissfeldt knows of de Vaux's work, but fails to heed it.

40. Supposed references to Terah as a lunar deity, etc.; of. Albright, BASOR 63 (1936) 27-32; R. de Langhe, Les Textes de Ras ShamraUgarit..., II, Desclée de Brouwer, Paris (1945) 469-519.

4I. Eissfeldt's interpretation of Isaac, Jacob and the latter's sons; he allows Abraham to be a real individual, as being a strongly marked personality; $c f$. Exodus ....6.

42. This rids us of such a priori speculations as those in Hebrew Kingdom I 3 ; the family usages are not secondary but primary (directly comparable with early second millennium data, and originating then). 
and conflicts of individuals have been interpreted as those of tribes and clans. This, in fact, is nothing more than a kind of romantic allegorizing of the text, ${ }^{43}$ a limbering-up of the imagination. And as de Vaux noted long since, ${ }^{44}$ this sort of procedure leads to absurdity in dealing with incidents such as the violation of Dinah (Gn. 34) or Reuben's misconduct (Gn. $35: 22$ ). And what whole tribes ever died of old age as did Abraham, Isaac, Jacob and Joseph? What tribes collectively had dreams as they did (Gn. 28:12-I7; 31:10-I3; $37: 5-10$ ) ? What tribe was ever sold for 20 shekels (Gn. 37:28, correct average price for one man at that period)? Again, while a tribe may bear the name of a prominent family head or founder, ${ }^{45}$ and the individual may be named after the tribe (gentilics), ${ }^{46}$ yet the patriarchal proper names are (as already noted) of kinds primarily used by individuals (relation- and 'Imperfective'- names), not groups. Eissfeldt (Exodus ... . $5^{-6)}$ offers us no scrap of rational and factual evidence for his assertions that 'it is pretty certain' that Jacob's sons were just personified tribal groups, and that much the same seems true of Isaac and Jacob. For Isaac and Jacob, he implies that their personalities are not so 'strongly marked' as that of Abraham, and so they are less personal.

On the contrary, Jacob has a perceptible and cunning personality all his own and on Eissfeldt's slender criterion should thus be classed with Abraham. Isaac's personality is not strongly marked-but people possessing retiring or lethargic or dull or other forms of 'quiet' personality are just as physically real and as numerous as strongly individual people, in any area or at any time for which we have proper evidence. So Isaac's modest role proves nothing of itself. The points already cited (plus the evidence of Genesis itself, the absurdities of allegorizing, and personal names) speak clearly against

43. Just like the fanciful Terachid, etc., interpretation of the Ugaritic texts (apart from the philological errors present in that case), $c f$. references in note $4^{\circ}$ above.

44. $R B 53$ (1946) 326 .

45. As in Bit-names of Aramaean and W. Semitic peoples in the Assyrian texts; and so with Israel (Jacob) and his sons in the Old Testament.

46. $C f$. de Vaux, loc. cit. 
Eissfeldt's view of Isaac and Jacob. Amongst the comparative material already sketched above, one may note the relevance of the close correspondences between the social usages of the patriarchs and the Nuzi and other data (pp. 7of., above) of the first half of the second millennium BG. The alliance of putative Abraham and Sarah clans or of theoretical Jacob/Israel and Rachel and Leah tribal groups might conceivably be pictured in terms of marriages between individual figures-but would such a picture (considered to be drawn up in and after the Hebrew monarchy, c. 1000-500 BC) ${ }^{47}$ reflect the irrelevant details and peculiarities of marriage, inheritance and other customs affecting individuals as such that were current in the first half of the second millennium BC (dying out later), for childless couples, saleability of a birthright and what not? All this intricate detail is incongruous and wholly out of place if imposed upon a set of generalized personifications of tribes and purely group-wanderings. And if no definite and specific traditions about actual founding fathers had come down to the supposed writers of the first millennium (monarchy and after), then how (short of doing some modern archaeology) should they either know of, or be able to impose on their material, a series of alien and obsolete customs from centuries before their own time? And why bother?

No; if the patriarchs were really generalized figures instead of real characters (strong or weak), if their stories reflected the conditions of monarchic and exilic Israel, or if their movements and activities took place in what was demonstrably a never-never land of legend, corresponding to no known consistent cultural background-then indeed we would have good reason to ask with Professor Eissfeldt whether they were in fact personifications (tribal or other) and what they reflected. This is clearly not the case: first and last their figures are those of individuals and their activities on the basis of external data correspond closely with those of real life observable at first hand.

\section{$B$ Historicity}

As already mentioned above (p. 66), no early extra-biblical 47. Cf. Eissfeldt, Exodus . . . 4. 
document actually mentioning any of the patriarchs has yet turned up, and so their absolute historicity cannot be proven mechanically by this means. But this does not rule out a less direct approach, using the external data in precisely the same way as one would do for other cases in the Ancient Near East.

As a concrete example, one might mention Anittas son of Pitkhana, king of Kussar, in Anatolia in the early second millennium BG, first known from tablets of the Hittite Empire of the fourteenth-thirteenth centuries BG published in the early I920s. ${ }^{48}$ After an introduction, the king narrates in the first person (as in the secondary 'narû-literature' of Babylonia ${ }^{49}$ ) his victories, rise to great-kingship over his contemporaries, and his buildings. Like these accounts, the Anittas account could have been considered as legendary or 'apocryphal'50 and there was then nothing to prevent anyone from regarding Anittas himself as purely fictional if they so wished. But soon Cappadocian tablets from Kültepe and Alishar were brought to notice that mention both Anittas and his father, and reflect Anittas's rise from subordinate to his father to becoming ruler and chief ruler; ${ }^{51}$ a dagger published in $195^{6}$ is inscribed 'Palace of Anittas'.52 Besides these subsequent material proofs for Anittas's reality and status, reassessment of the Boghazköy tablets in the light of the external comparative data of his day and of the archaic language and stylistic arrangement shows that the Deeds of Anittas must be taken seriously as an original historical document. ${ }^{53}$ Here we have a text whose features fit the historical date indicated by its contents when compared with external data, and a personage whose existence was no

48. Cf. references in H. Otten, Mitteilungen der Deutschen Orient-Gesellschaft 83 (1951) 38-39.

49. $C f$. O. R. Gurney, $A S 5$ (1955) 93 and references.

50. Less severe doubts were expressed in various quarters, e.g. formerly by K. Bittel, Boğazköy [I] (1935), Abh. Akad. d. Wiss., Berlin, I 3 n. I.

51. $C f$. note 48 above, for references.

52. For the dagger, $c f$. T. Özgüç, Belleten T.T.K. $20 /$ fasc. 77 (1956) 33ff.; Gurney, $C A H^{2}$, II :6, Anatolia, c. $1750-1600 B C$, Cambridge University Press (I962) 7.

53. $C f$. Otten, op. cit. (note 48 above) $43-44$. As often in the Near East, the orthography of the text has been modernized during the course of repeated recopyings, but Otten notes one notable surviving archaism (Old Babylonian NE). 
more certain than that of the patriarchs, before the Cappadocian tablets and Kültepe dagger brought material proof.

Similarly, there was nothing to discourage scepticism over early Sumerian rulers in the Sumerian King List such as Enmebaragisi (whose regnal figure of 900 years hardly helped matters) - until a contemporary text mentioning this king was published.54 In Egypt, the king Nephercheres attributed to the XXIst Dynasty by Manetho was either wrongly identified with the high priest Pinudjem I or simply dismissed altogether, until Montet found his name and titles as Neferkarē'Amenemnisu on objects from the burial of Psusennes I at Tanis, and his name was then recognized in a famous genealogy in Berlin Museum. ${ }^{55}$ Egyptologists accord high value to the report known as the Travels of Wenamun; the Egyptian rulers Smendes and Herihor are well enough attested, but no (other) contemporary objects can yet be brought forward to prove the existence of either Wenamun or his Syrian contemporaries and hence the widely accepted official status of his report. ${ }^{56}$ Plenty of examples exist of ( $I$ ) people for whom direct attestation has come late but has in due time confirmed the indirect data, and (2) people for whom such later attestation has never yet turned up (and may never do so) but whose former reality is a reasonable assumption on the available comparative evidence of the same indirect type as for ( $\mathrm{I}$ ) before direct confirmation came to hand.

There is no reason to treat the patriarchal narratives any differently. They depict the movements of one Abraham and his relations from Ur in Mesopotamia to Harran and thence to Syria and Palestine; his descendants continue to circulate in Palestine as semi-nomads until driven into Egypt by famine, one of their number already being there.

As has been pointed out above, a whole series of features in

54. Cf. D. O. Edzard, $Z A 53$ n.F. 19 (1959) 9-26.

55. Cf. P. Montet, Psousennès, Paris (195I) 185; B. Grdseloff, Annales du Service des Antiquités de l'Egypte, 47 (I947) 207-2 I I.

56. E.g., by W. Helck, Die Beziehungen Agyptens zu Vorderasien ... Harrassowitz, Wiesbaden ( 1962 ) 396 , following on considerations by J. Cerný, Paper and Books in Ancient Egypt, H. K. Lewis, London (1952) 22. 
the narratives can be systematically compared with the external data:

I. Personal names of readily paralleled types, especially early second millennium BC.

2. Semi-nomadic movements ( $c f . \mathrm{J}$. R. Kupper, Les Nomades en Mesopotamie ..., I957) and wide general contacts in the Old Babylonian period.

3. Social customs show an intricate correspondence with Nuzi (and earlier) data, not with later ages.

4. Political conditions (coalitions) in Mesopotamia (Gn. I4) correspond to those of the Old Babylonian period, not others.

5. Conditions in Palestine are realistic:57 city-states with tribal hinterlands (as in Execration Texts).

6. 'Archaeological demography' of Transjordan and the Negeb fits certain patriarchal data (for early second millennium BC). ${ }^{58}$

7. Patriarchal religion (God of fathers; role of $\mathrm{El}$ ) fits external data (especially in early second millennium Ba). And so with other data.

The rational deduction from all this is that all the principal data of Genesis on the patriarchs when lined up with the corresponding external material either speaks directly for a date in the first half of the second millennium BC, say c. 2000I 700 (so points I in part, 2, 3 in part, 4,6, 7), or agree well with such a date though not restricted to it (points $I$ and 3 in part; 5). The more specific and specifically datable items represent matter that really must have had its origins in the early second millennium $\mathrm{BG}$ and was transmitted reliably enough to the late second and early first millennia (and thereafter preserved) to be clearly recognizable today. At every turn of the narratives, we find the patriarchs involved in activities

57. $C f$. Sinuhe-also realistic. Whether or not Sinuhe himself is historical (and his story), neither he nor the other people in his story (e.g. Ammu-nenshi) are personified tribes, former Egyptian or Canaanite deities, etc.!

58. For the Negeb, $c f$. N. Glueck, Rivers in the Desert, Weidenfeld \& Nicholson, London (1959), and reports in BASOR, Nos. I31, 137, 138, 142, 145, I49, 152, I 59 (1953-1960). For Transjordan, Glueck, The Other Side of the Fordan, ASOR, New Haven (1940), and elsewhere. 
and customs of real life in the early second millennium BCand not of some imaginary cloud-cuckoo land. ${ }^{59}$ Hence it is not unreasonable to conclude that not only the very precise (and in part, chronologically limited) activities and customs but also the figures enmeshed in them once had historical reality, as much as Anittas or Wenamun and many more. This is an assumption, a hypothesis, but it is a fair and methodologically justified assumption in the present state of knowledge, and may legitimately be presented as a working hypothesis. ${ }^{60}$

59. Longevity of the patriarchs, however regarded, is irrelevant to the question of historicity; $c f$. Enmebaragisi, mentioned above, assigned a reign of 900 years!

6o. See also E. A. Speiser, Genesis, Anchor Bible, Doubleday, New York (1964) xxxvii-lii; Speiser's treatment (using the conventional documentary hypotheses) shows that literary criticism per se has no necessary bearing on essential historicity of the patriarchs. The 'historian's protest' (sic) by S. Mowinckel, Tetrateuch-Pentateuch-Hexateuch, Töpelmann, Berlin (1964) 79, against deciding the historicity of the patriarchs on socio-legal correspondences with the 'Mari documents' (sicwhat of Nuzi and all the rest?) is itself wide of the mark. The close correspondence between the details of the patriarchal narratives and a whole range of external data (not just Mari, and not only societal) of the first half of the second millennium BC does not prove the real existence of the patriarchs ( $f f$. already above)-but it does favour that view (cf. Anittas, Nephercheres, Wenamun and plenty more) and speaks heavily against an a priori assumption (uncritically borrowed from Gunkel) that the narratives are but fairy tales. Mere tales can and sometimes do use 'realistic' details; but not a consistent series of 'archaeological' usages from centuries before the supposed narrators lived! Gunkel wrote sixty years ago when the present mass of detailed background was unknown, and (through no fault of his) his ideas are wholly obsolete (because pre-scientific, strictly speaking) on this subject today. The quality of Mowinckel's 'historian's role' may be judged from his defence of extensive application of aetiology to Old Testament narratives (op. cit. 78-86). Conscious of the effective onslaughts by Albright and others (notably J. Bright, Early Israel in Recent History Writing, SCM, London (1956)) on the abuse of this principle by such as Alt and Noth, he rests his case on the thesis that scholars in the brave new world of America cannot be expected to have a proper appreciation of aetiology and tale-telling like their colleagues in the old Kulturländer of Europe! I have rarely seen a more fascinating or more improbable proposition! He includes British scholars (78) in his criticism; I would gently suggest that we over here are as good an old Kulturland as anywhere in Western Europe, but our common-sense and appreciation of facts and proper historical method are perceptibly greater than those of the late lamented Professor Mowinckel, whatever our other faults maybe. 
In fact, in the light of the evidence available, the onus of proof lies on those who would favour contrary views (such as tribal personifications, old deities, or pure legends).

One is entitled to ask just why the early Hebrews should faithfully retain and transmit the memory of a whole body of increasingly antiquated customs and conditions if there had never been any real individuals to attach them to in the first place (they are irrelevant to collectivities like tribes), and why they should invent figures upon which to hang these pointless antiquities if there had been no Abraham, Isaac, Jacob or sons.

The analogy of Near Eastern historical studies (e.g., Anittas, Enmebaragisi, Nephercheres, Wenamun and a myriad more) and the ready correlations between Genesis and external material alike point to the more commonsense solution of provisional/probable historicity suggested here.

\section{THE DATE OF THE PATRIARGHS}

As already quite sufficiently indicated above, ${ }^{61}$ personal names, occupational history of Transjordan and the Negeb, scope of travel, religious matters, social and legal usages, Mesopotamian alliances, Palestinian conditions, and even slave-prices (Joseph) -all point clearly to, or agree with, a date of c. 2000-I 700 BC for the patriarchs. With an Exodus in the thirteenth century BG, this agrees well with the 400 (round figure) or 430 (more specific) years between Jacob's entry into Egypt and the Exodus under Moses.

In the light of all this complex and interlocking material, Eissfeldt's treatment of the date of the patriarchs (Exodus ... 8-ro) is clearly inadequate, and distinctly misleading for the general reader. His date in the fourteenth century BC clashes wildly with all the primary and positive evidence so far mentioned, and cannot be justified on the grounds he offers. The four generations alleged between the time of Jacob and that of Moses is illusory; the four dôr of Genesis $15: 16$ have been

Tangible comparative data, properly used, are worth infinitely more than pseudo-psychology.

61. Covered with fuller documentation in my Alter Orient und Altes Testament (1965); Ancient Orient and Old Testament (forthcoming). 
appropriately compared with West Semitic and Old Assyrian daru, and in all probability are simply another way of expressing the 400 years of verse $13 .{ }^{62}$ The supposed four generations from Moses to Levi (Ex. 6:20) is not a full genealogy, ${ }^{63}$ but simply gives the tribe-clan-family affiliation of Moses and Aaron. ${ }^{64}$ This kind of material cannot be used to contradict the requirements of the $400 / 430$ years or of the primary external evidence already referred to so frequently above. ${ }^{65}$ The appeal to supposed later conditions is worth very little. Camels are not anachronistic in the early second millennium BC, but find only sparing attestation and use both in Genesis and external sources then and until the twelfth century BC. $^{66}$ In dealing with Isaac's Philistines, Eissfeldt fails to check on the evidence for Aegean connections with, and penetration into, Palestine and neighbouring lands in the early second millennium $\mathrm{BG}$, or to consider that the term 'Philistines' may merely date itself (not the incidents in Genesis), very possibly replacing an older term such as Caphtorim ( $c f$. Egyptian Keftiu, and Kaptara in the Mari archives and having relations with Hazor in Palestine) ${ }^{67}$ In view of all the other evidence pointing back to the first half of the second millennium $\mathrm{BG}$, he surely ought to have

62. Cf. W. F. Albright, BASOR 163 (1961) 50-5I.

63. As was long ago pointed out in J. D. Davis, ed. H. S. Gehman, Westminster Dictionary of the Bible, Collins, London (1944) $153 \mathrm{~b}$ (longer parallels).

64. Cf. D. N. Freedman in G. E. Wright (ed.), The Bible and the Ancient Near East, Kegan Paul, London (I96I) 206-207; also missing from Eissfeldt's bibliography.

65. One should note that Ex. I :8 does not say that the pharaoh whose oppression led directly to the Exodus was the immediate successor of Joseph's pharaoh; this is simply Eissfeldt's own interpretation of the text. The text merely mentions 'a king that knew not Joseph'; as Joseph was clearly dead and buried (Gn. 50:26) and the Hebrews had considerably multiplied (Ex. $1: 7$ ), the text is normally interpreted to mean that the king who knew not Joseph was long after him, and had not even heard of him, Joseph's fame having had long enough to die away except among his descendants and their relations.

66. See provisionally in Bruce, Packer, etc., eds., Nere Bible Dictionary (1962) 181-183.

67. For this topic and relevant references, see my Alter Orient und Altes Testament (1965) 35 and Anmerkungen 209-217; Ancient Orient and Old Testament (forthcoming), 'Some Historical Points', i, (b). 
done so. His interpretation of Genesis 27 in terms of 2 Samuel 8 is pure romantic supposition, lacking any kind of verification.

The ambiguity alleged in the external data (Exodus . . . 8-9) has been shown above to be quite baseless. It is perfectly true, of course, that none of the kings named in Genesis 14 has yet been securely identified with individuals so far known from external sources. But however desirable, this kind of correlation (often missing for other Near Eastern kings) is not the only possible contribution of Genesis 14 to patriarchal chronology. The names of the kings are of kinds well known in the Old Babylonian period-Arioch is the same as the Arriukki, Arriwuk, of Mari and Nuzi; Tid'al is the same as Tudkhalia occurring in the Cappadocian tablets as well as being the nomen of later Hittite kings; ${ }^{68}$ Chedor-la'omer is typically Elamite, the elements Kudur and Lagamal/r occurring from the early second millennium $\mathrm{BC}$ and later. The Old Babylonian date of groups of allied kings in Mesopotamia has been sufficiently stressed above. Eissfeldt rightly dismisses (10) erroneous use of the Amarna tablets. But his final statements in $\S$ II on p. Io could hardly be more grossly misleading. That 'the narratives concerning them [= the patriarchs] point more probably to the two centuries [= fifteenth/fourteenth] immediately preceding the final land settlement of Israel $[=$ thirteenth century and following, $c f .17-18]$ than to the first half, or rather the first third, of the second millennium or to yet older times' is palpably contradicted by the close and sometimes exact correlations between these narratives and the data of the early scond millennium BC. That 'this earlier dating [= early second millennium] depends .... on the figures given in Exodus xii. 40 and I Kings vi. I' is also almost wholly untrueit depends on the whole complex of phenomena (tied to the early second millennium BC) so often referred to already, andsecondarily agrees also with Exodus I $2: 40-4 \mathrm{I}$ and related data.

68. Tid'al as 'king of peoples' is very much like the ephemeral federal chiefs (rubä'um rabium) of Anatolia known from the Cappadocian tablets (A. Goetze, Kleinasien2, Beck, Munich (1957) 75, refs.; P. Garelli, Les Assyriens en Cappadoce, Maisonneuve, Paris (1963) 206 and n.4, 205-215); or like a chief of the Umman-manda such as Zaluti (cf. H. Otten, Mitt. d. Deutsch. Or.-Ges. 86 (1953) 6r, 63). 
In short, Eissfeldt's treatment of the date of the patriarchs simply cannot be squared with the facts available today.

IV. ARBITRARY METHODS; ERRORS

\section{(a) 'All Israel'}

\section{A Arbitrary Procedure}

Wherever this idea appears in relation to pre-monarchic Israel, it is peremptorily rejected by Eissfeldt in flat contradiction of all the Old Testament sources. $\mathrm{He}$ is well aware that the participation of all 'Israel' in the Palestinian and Egyptian sojourns, Exodus and Conquest has the unanimous backing of all our extant traditions. ${ }^{69}$ This fact should have given him cause for caution before flying in the face of so persistent a tradition. But not so; he categorically dismisses the idea as: 'an anachronism, with consequences that are not historical' (Exodus . . . 4), it 'cannot, in any circumstances, be correct' (idem. I5), 'this conception is erroneous' (id. I6), 'unhistorical' (id. 24; Hebrew Kingdom, 9), 'a secondary development' (Hebrewe Kingdom, 7), 'not historical' (id. I0-I I).

For so determined a rejection of so persistent an element, we are entitled to explicit evidence and solid reasons-but none are forthcoming! In Exodus . . . I6, reference is made back to 'the general considerations already stated'. Herein lies both a fallacy (detailed proof, not just a few broad generalizations, is required to justify so bold a position) and even a deception. The latter, because in looking back to p. 4 , no evidence as such, either specific or general, is offered for Eissfeldt's position. $\mathrm{He}$ merely states categorically that 'all Israel' is 'an anachronism', and founds his following observations on that initial assumption (unproven though it be), these observations themselves merely constituting a series of unsupported assumptions. Again, on pp. I4-15 of Exodus ...., the rejection of the 'all Israel' concept is simply assumed as if it were a fact, and used accordingly, and no supporting evidence is quoted to allay the mistrust of the scholar or to inform the queries of the general reader. On p. I6 itself, all Eissfeldt can do is to stress the importance of Joseph and his descendants. However, the

69. Exodus . . 4: 'All the narrative works, even the oldest . . . 
prominence of one member or clan in the group (in sojourn or exodus) does not prove that it alone was involved. Why does Eissfeldt offer us no evidence, no proof, for his rejection of 'all Israel'? For the simple reason that none exists. Apart from the sole mention of 'Israel' on the Israel stela of Merenptah (see below, pp. 90-92), our only source of information is the Old Testament-and the Old Testament offers no support for any view except that of 'all Israel'; here, all of Jacob's surviving family went to Egypt, and descendants of him and his named sons left Egypt four centuries later along with a mixed body of 'fellow-travellers' (Ex. I $2: 3^{8}$ ).

From the point of view of historical method-of the use of explicit evidence, and external data as opposed to pure guesswork and unverified opinion-then, Eissfeldt's rejection of the 'all Israel' tradition must itself be firmly rejected as a major procedural error in his presentation. With it go his dependent suppositions. There is no ground for rejecting the chronological sequence of Abraham-Isaac-Jacob (contrast Exodus . . 4). That succession is part of the very core of the patriarchal narratives. Genesis I5-2I is repeatedly overshadowed by the question of Abraham's posterity-Eliezer, Ishmael and at last Isaac-and is specifically tied up directly with the customs of the early second millennium BG (Ur, Lipit-Ishtar, Nuzi); Genesis 22 and 24 indissolubly link Abraham and Isaac. In Genesis 25, the birth of Esau and Jacob to Isaac is a special topos, and Genesis 27-28 are meaningless without the relationship of Isaac to Esau and Jacob. Again, the birth of sons to Jacob by both handmaids and chief wives (Gn. 29:3I-30:24) directly reflects the early second millennium practices already cited; and the story of Joseph demands for its intelligence the close links between Jacob and his sons and Joseph and his brothers as given. To treat all this as secondary means abandoning the patriarchal narratives solely in favour of an arbitrary principle, and in the face of the whole weight of external, generally recognized comparative material that links such 'secondary'(!) matter directly with the first half of the second millennium BC. Equally (p. 4), there is no greater reason to reject the itineraries of the wilderness journeyings 
(also, p. 20) for the sake of the same purely arbitrary principle. The role of 'all Israel' in the conquest under Joshua is not, then, a mere 'preconception' to be dismissed as 'secondary' (Hebrew Kingdom 7), but primary and universal in the Hebrew traditions.

Eissfeldt almost completely ignores the work done on the Sinai covenant in recent years, mainly as a result of Mendenhall's study of i954 (Biblical Archaeologist I 7, and reprinted), especially the affiliations of form between the Sinai covenant and a whole series of treaties or covenants of the thirteenth century $\mathbf{B C}$, the period of the Exodus and wanderings. ${ }^{70}$ In a work published in 1965 , this neglect is inexcusable. Moreover at certain points Eissfeldt is compelled to admit the existence of evidence for a feeling of unity among the Israelite tribes long before David. Here, one may cite the Song of Deborah in Judges 5 (cf. Exodus . . 22-23; Hebrew Kingdom 14-15) where the entity 'Israel' is at home (verses 2, 7, 8, 9, I I ; 'God of Israel', 3, 5); Ephraim, Benjamin, Issachar, Zebulon and Naphtali are praised for their roles, while Reuben, Gilead (probably Gad and E. Manasseh), Dan and Asher are reproached for their inactivity and were obviously expected to be ready to help. Only Judah and Simeon are omitted (reasonably, for in the far south they were too far away to have lent rapid aid) and of course the Levites (devoted to cult). Hence, this Song constitutes direct evidence for the ideal unity of ro out of 12 or 13 tribes; to observe these facts and then promptly state as Eissfeldt does (Hebrew Kingdom I $_{5}$ ) that 'the song in no way constitutes a proof' of the existence of (or idea of) an entity 'Israel' represents a non sequitur. The feeling of unity is attributed by Eissfeldt (Exodus . . . 23) to a religious basis, traced back by him to pilgrimages to Qadesh and Sinai. For early pilgrimages thither of this kind we have no proper, explicit evidence at all; but the Sinai covenant which looms so large in Exodus and Deuteronomy was of a form that connects it with the thirteenth century $\mathrm{BC}^{71}$ and this is a more

70. For the covenant forms, we at least have tangible comparative data; for the particular pilgrimages postulated by Eissfeldt (p. 23), nothing at all.

71. Cf. Mendenhall, op. cit., and the section on 'Religious Contacts' in the work(s) cited in note 67 above. 
realistic and stable religious basis than imaginary pilgrimages.

Even then, this does not explain why some people joined in the Sinai covenant and others (e.g., Midianites, Kenites, Jerahmeelites, etc.) never did ( $c f$. Exodus . . . 23), despite their supposed interest in Qadesh or Sinai as sacred spots.

The primary appeal in Exodus $(2: 24 ; 3: 6-7,13-17 ; 4: 5$; $6: 3$ ) is to the God of the fathers-Abraham, Isaac and Jacobwhose special name was YHWH. This appeal would not make sense to the Hebrew tribes in Egypt unless they claimed Abraham, Isaac and Jacob as their ancestors, through the sons of Jacob who had become eponyms of their tribal groups. Thus, one may justifiably view the Hebrew tribes in Egypt as having among themselves a tradition of their forefathers' entry into Egypt, each with a son of Jacob ${ }^{72}$ as eponym, Jacob being the last of the three great ancestors. Such groups recognized $\mathrm{El}$ as God of these (fore)fathers; other West Semites in Egypt but outside that tradition would not. Some threw in their lot with the escaping Hebrews (Ex. 12:38, 'mixed multitude'), and perhaps affiliated with the various Hebrew tribes. Hence, it was the inherited tradition that determined who went forth and then joined in the covenant at Sinai, constituting the 'sons of Israel' or just 'Israel'-and not some vague religious feeling, leaving unexplained ${ }^{73}$ the non-participation of other groups like the Midianites, etc.

Thus, the 'all Israel' idea is in all probability a direct reflection of an actual nucleus of Hebrew tribes who claimed descent from the sons of the last of the 'founding fathers' whose God they nominally served. No doubt, other W. Semites in Egypt joined with them, or there was intermarriage, and such would be drawn into the common basic traditions, but this is not demonstrable now and of minor practical account then, for our purpose; 'all Israel' is an ancient concept.

(b) Distinction and Confusion of the Patriarchal and Conquest Epochs

Eissfeldt fairly and candidly admits (Exodus ... I I) the clear sequence and separateness of the three phases: patriarchs,

72. Or grandson in the case of Ephraim and Manasseh, sons of Joseph.

73. Apart from mere caprice, or specific reasons left unstated (both theoretically possible). 
Egyptian sojourn, settlement in Canaan, in the extant Old Testament traditions. He then promptly suggests by contrast that 'the interval [between especially patriarchal and Conquest periods] is not so clear-cut' and that this 'can be shown by two or three examples' (I I, end). In view of the clear separation of four centuries between the patriarchs and the land settlement under Joshua and the judges, one turns with interest to Eissfeldt's examples; three may be discerned.

I. It is suggested (p. 12, top) that Reuben's misbehaviour with Jacob's concubine should precede the attack on Shechem by Simeon and Levi, and that both incidents are 'literary inventions, poetic symbolizations, to account for the fall of those tribes [Reuben, Simeon, Levi] from their former importance into weakness and dissolution as [being] due to misdeeds of the three eponymous ancestors of the tribes'. All this is, by definition, pure speculation, and does not constitute evidence in any normal sense of that word. The change of order of Reuben's and Simeon's deeds is pointless; the fictional nature of these narratives requires to be proved, not assumed. Eissfeldt himself quickly admits that the view he has just quoted may not be true, and hence the stories of Reuben, Simeon and Levi could precede 'by a considerable period' the land settlement under Moses and Joshua. Where Eissfeldt himself is so divided in mind, how can these opinions possibly constitute evidence for closeness in time of the patriarchal and conquest epochs?

2. Similarly (pp. I2/13), Eissfeldt would in practice read the fortunes of the sons of Leah (Reuben, Simeon, Levi, Judah, Zebulon, Issachar) as an allegory of an attempted occupation of Canaan from the south by the corresponding tribes, but 'at a time earlier than the final conquest'. If earlier, then the activities of Jacob's sons (however interpreted) cannot be linked with the initial conquest of Moses and Joshua, and in fact there is no real warrant left to take them as anything else but traditions about the patriarchs themselves (regardless of their truth or fiction). Eissfeldt then adduces passages in Numbers, Joshua and Judges in relation to his theme. The fact is that these passages $d o$ explicitly concern the conquest- 
period; they are totally irrelevant to the patriarchs. The fight of Simeon and Levi and their adherents with Shechem has no direct bearing on the conquest period.

3. On p. 13, Eissfeldt suggests further that the story of Issachar would yield a date for the conquest of certain areas by Leah tribes; Labaya of Shechem (Amarna letter No. 250) destroyed Shunem, and one may connect this with the settlement of Issachar in Jezreel at the cost of their independence, soon after Labaya's success. Eissfeldt's source for this construction is an old study by Alt. ${ }^{74}$ The latter compared the judgment on Issachar in Genesis 49:I5 (becoming a servant in taskwork or corvée, mas-'obed) with the mention of mazza, 'corvée' in connection with Shunem and two other places in an Amarna letter from a prince of Megiddo. ${ }^{75}$ This chance coincidence of two references to so everyday a Near Eastern institution as the corvée in connection with central Palestine can hardly be offered as serious evidence for the date of Issachar's settlement in central Palestine, nor can the destruction of Shunem in Amarna letter No. 250. This is all just reckless guessing. Labaya of Shechem is post-patriarchal (Hamor was in Shechem then) and pre-Hebrew conquest.

In other words, the three phases: patriarchs, Egyptian sojourn, settlement in Canaan, remain a clear and distinct sequence; Eissfeldt has provided some interesting guesswork in his 'examples' but not a particle of fact to verify or support any other view, as one would expect in a serious history.

\section{$B$ Error}

\section{(c) The 'Israel stela' of Merenptah}

Eissfeldt professes some doubt as to the date at which the Israelite tribes actually came to be called 'Israel', between the patriarchal age and some time well after the initial conquest. This, of course, depends on how one chooses to treat the biblical data; Professor Eissfeldt is fully entitled to his own

74. A. Alt, Kleine Schriften, III, Beck, Munich (1959) 158-175, from Pälastina-7ahrbuch 20 (1924) 22-41. See pp. 173-5 (=40-4r).

75. Published by F. Thureau-Dangin, $R A$ I9 (1922) 91-108 (Mercer's No. 248a). 
opinion (preferably with some facts to support it). However, he goes on (Exodus . . . I4) to make the following remarkable statement: 'Unfortunately, even the supposed earliest mention of the name Israel in the triumphal hymn of Merenptah . . . does not provide any unambiguous answer to this question, for this name may also be explained as Jezreel' (our italics).

The second half of this statement (here italicized) is, significantly, undocumented and rather takes one's breath away. It is a philological impossibility of the first order. The name on the Merenptah stela is consonantally $Y_{s r}$-'ir for $^{\prime} r_{s r-'} i l$ (no $l$ in written Egyptian). This corresponds exactly to Hebrew

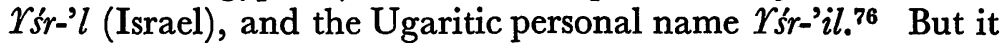
differs completely in two vital points from 'Jezreel'. The latter is consonantally $r z r^{6}-$ (') , with medial $z$, not $s$, and an 'ayin that is wholly lacking in both 'Israel' and the Merenptah stela. W. Semitic $z$ appears in Egyptian as $\underline{d}$ or $\underline{t}^{77}$ and not as s; 'ayin cannot be omitted except as a gross scribal error where none is to be inferred. No competent scholar today doubts the philological equation of Hebrew $Y^{\prime} r$-' $l$ and Egyptian $Y s r-i l$ -and none is likely to prefer $Y s r^{\prime} i l$ to $* Y d r^{i} i$ (or $* \gamma t r^{6}-$ ) $-i l$ as an Egyptian transcript of $r z r^{6}-' l$ (Jezreel)! Professor Eissfeldt is therefore in danger of conviction of special pleading on this particular point.

However, even a provisional acceptance of the proper equation $Y^{\prime} s_{-}-l=r_{s r}-i l$ later on (Hebrew Kingdom 8) still finds Eissfeldt refusing to face up to the clear implication of Merenptah's stela ${ }^{78}$ that a people or group Israel had had some kind of contact with Merenptah's forces in W. Palestine, along with Gezer, Ascalon and Yenoam, c. I230/1220 BC. He would claim that, besides the Israelites (or 'House of Joseph') under Joshua, there may have been an older group of the same name

76. In Virolleaud's transcription ( $P R U, \mathrm{~V}\left({ }_{1965)} 97\right.$, No. 69:3); $Y_{3 r}^{\text {r }}$-il on Gordon's system.

77. Cf. W. Helck, Die Beziehungen Ägyptens zu Vorderasien . . . 589, 554:18, for this.

78. That Merenptah did intervene in W. Palestine, even if only modestly and briefly, is clearly indicated by his inscription in the temple of Amada in Nubia; here, he bears the special title 'Binder of Gezer' precisely parallel with the special epithet 'Seizer of Libya'-which is known to commemorate his famous Libyan war. 
in W. Palestine. His 'evidence' for this supposed older 'Israel' group is Genesis $32: 24-32$ and Genesis $33: 20$, the story of Jacob's wrestling at Penuel (and being named Israel) and a note of his erecting a suitably named altar on land bought near Shechem! Both incidents are attached to the individual Jacob, not a people. The explanation of this astonishingly irrelevant evidence is presumably given in Exodus . . . I4, where Eissfeldt invokes the theory that 'Israel' was a name native to Canaan probably picked up there by the Jacob tribe (not individual). For this theory, there is no verifiable evidence; as already indicated above, Jacob in the patriarchal age was an individual, not a tribe, and the one other nonbiblical (Ugaritic) reference above cited is, again, the name of a single person, not of a people. In other words, there is no reason at all to adopt anything other than the straightforward explanation for the Israel of Merenptah's stela, namely that it is the group of tribes led by Joshua and the Judges. The same highly improbable theory of an earlier doublet of Israel has been mooted by Noth. ${ }^{79}$ One may just as well argue that the 'Moab', 'Seir' and 'Edom' mentioned in Egyptian texts are also doublets, different from their Old Testament homonyms! The grotesque position adopted by Noth and Eissfeldt is the result of preferring their own theories to the evidence of first-hand data and of their consequent refusal to face up to such data (in this case the Israel stela). Casuistic acrobatics of this kind have no place in a work of the class and scope of the $C A H$.

\section{OTHER ASPEGTS}

Much more could be added, but not to prolong this melancholy survey unduly, only one or two additional points may be noted in token of the rest.

\section{A Literary Criticism}

In both fascicules, Eissfeldt states the results of conventional Old Testament literary criticism in absolute terms as if they

79. History of Israel2 (I960) 3. Uncritically repeated by S. Herrmann, Zeitschrift für Ägyptische Sprache 91 (1964) 68 n.2. 
were proven facts. He states apodictically (Exodus . . 3) that 'The Pentateuch constitutes a combination of several distinct narrative works ..., and (Hebrew Kingdom 3) that 'the book of Joshua certainly presents a combination of narrative elements that are parallel to one another, ... exactly .. . as the Pentateuch does'. Now, this is not strictly so. No physical proof (i.e., Mss, direct attestations) has ever yet come to light for the existence of ' $J$ ', ' $E$ ', ' $P$ ' or other such documents, any more than for Abraham, Isaac or Jacob. And various scholars or groups of scholars ${ }^{80}$ have serious objections to the whole system. The author's personal conviction of the reality of such documents would have been better presented as a personal opinion. The commendable caution shown in dealing with Judges, Samuel and Kings (Hebrew Kingdom 3) could be applied equally well to the Pentateuch and Joshua.

However, his apodictic statements of these latter are still less defensible in that his Pentateuchal and Joshua 'sources' include not only J, E, D, P, but also the 'lay source' (' $L$ '), first distinguished by Eissfeldt $-a$ document and siglum that does not enjoy anything like the same common acceptance as the four just mentioned. In a general work such as $C A H$ the majority view is surely accepted in the text, the author's own construction in a footnote, or if allowed in the text, certainly noted as a particular viewpoint not universally accepted.

\section{$B$ Other Points}

I. The treatment of the Conquest (Hebrew Kingdom $7 \mathrm{ff}$. ) endorses the long outdated view that Judges $I-2$ is to be opposed and preferred to Joshua I-I I, citing (ibid. 7 n.I) obsolete works of the early thirties and ignoring the positive results of such a systematic comparison of archaeological and biblical data as that conducted by G. E. Wright. ${ }^{81}$ An initial period of campaigning by Joshua and 'all Israel' temporarily

8o. E.g., by the Scandinavian Old Testament scholars; for more fundamental doubts, see my remarks, $\mathcal{F E A} 47$ (196r) 162-164, plus C. H. Gordon (refs., ibid. 163, n. 14), M. H. Segal in C. Rabin (ed.), Scripta Hierosolymitana VIII (I96I) 68-I I4, W. W. Hallo, IEJ I 2 (1962) I3, 14, 26 end, and others.

81. JNES 5 (1946) 105-1 14. 
broke the power of various city-states, but did not achieve an immediate settlement-occupation of the country, a task largely left to the individual tribes when central leadership ceased. The basic picture in Joshua is neither 'unhistorical' nor in such need of being 'corrected' (ibid. 9). Eissfeldt chooses to illustrate his a priori dogma of 'all Israel' being a reading-back in time and extent of tribal successes from the defeats of Hazor in Joshua II and Judges 4-5. As these narratives-in every other way different-both have a Jabin as king of Hazor, Eissfeldt would suggest that they record the same event, Baraq's deed being attributed to Joshua. But community of royal name proves nothing-a Jabin $I$ and II is no more exceptional (or exceptionable!) than, say, an Ammistamru I and II and Niqmad II and III at Ugarit, or a Mursil II and III in Hatti, or a Sethos I and II and Ramesses I and II in Egypt, all in the fourteenth/thirteenth centuries BC. The suggestions for re-attribution of activities of Joshua (Jos. Io) and Moses (Nu. 2r) in ibid. ro, are hypotheses for which we possess no supporting evidence; they have, therefore, no place in a serious history - except, perhaps, in a footnote and clearly labelled as guesses. However, in considering the conquest period, let it in all fairness be stressed that Professor Eissfeldt does rightly recognize the essentially warlike nature of the Israelite penetration of Canaan.

2. The speculations about Shamgar's patronymic Ben-'Anath (ibid. 22) are somewhat out of touch with modern knowledge of this class of names. The form Ben-(deity) is well enough attested, and specifically the name Ben-'Anath (variously spelt) from Ugaritic, Amarna and Egyptian sources; names of deities (including 'Anath) can themselves be used by mere humans. ${ }^{82}$ Thus, the interpretation of Ben-'Anath as a phrase for ' $a$ brave hero' is wide of the mark. While Shamgar Ben'Anath could conceivably stand for Shamgar ben (citizen of) Beth-'Anath, yet it is far more likely to stand for Shamgar ben (son of) Ben-'Anath, with omission of one of the two identical

82. See the excellent and detailed summary of documented examples given by J. T. Milik, BASOR 143 (1956) 3 , in an important paper for the Judges period, absent from Eissfeldt's bibliographies. 
elements, if not simply for Shamgar ben/son of (a person called) 'Anath. Shamgar in Judges 3:3 I was clearly an ephemeral deliverer of the Israelites from Philistine 'oppression'; he is not, therefore, included 'erroneously' (as Eissfeldt states, ibid. 22). Eissfeldt's statement that in Judges $5: 6$ Shamgar is shown as an oppressor of Israel is purely his personal interpretation and is not stated by the text. All that Judges $5: 6$ does is to reflect the ineffectiveness of Shamgar's short-lived deliverance.

3. Eissfeldt's evaluation of I Samuel 8 (Hebrew Kingdom 38) as 'not . . . a historical record of facts but a tendentious distortion of the truth' is itself out of date, tendentious and hence misleading. Ever since 1956 when the basic facts were collected and set forth by I. Mendelsohn, ${ }^{83}$ it has (or should have) been common knowledge that the powers of a king as pictured in I Samuel 8 are not a description of abuses and corruptions of power, but simply a firm warning of the normal cost of monarchic government as exercised in 'the nations round about'. The detailed cuneiform evidence (in legal and allied documents, hence not blatantly abuses!) comes principally from Alalakh and Ugarit; and, comparable clause by clause with I Samuel 8, clearly portrays everyday practices in the Syrian area, not erratic acts of despotism. ${ }^{84}$ This should have been known to Eissfeldt and used by him, instead of his merely repeating the shibboleths of Old Testament scholarship of six or eight decades ago.

4. It is, by contrast, a pleasure to read the relatively balanced and informative account of the reigns of David and Solomon and to take notice of the many useful points brought out in the course of Eissfeldt's survey of these two reigns. At random, one notes his up-to-date utilization of Miss Kenyon's work at Jerusalem, the delineation of relations between David and the Philistines, Solomonic commerce, Solomon's buildings, palace-furnishings (especially his throne), role in wisdomliterature, and visit from the queen of Sheba, to name some

83. BASOR I43 (1956) 17-22-a well-known, fundamental and oftcited study, again missing from Eissfeldt's bibliographies.

84. It may be remarked apud Eissfeldt's allusions to conditions in Edom, Moab, Ammon and Aram, that external evidence on I Sa. 8 from these kingdoms is all but totally lacking at present. 
examples. Needless to say, a variety of other details are open to alternative treatments but need not be discussed here. Instead, a caution may be entered in view of the numerous significant bibliographical references given by Professor Eissfeldt in $C A H$ and in other writings of his, which he fails to utilize for discussion in his text. The example here is the stables at Megiddo. Eissfeldt lists in his bibliography (IX, $5 \mathrm{I}$ ) Y. Yadin's article showing that the Megiddo stables are later than Solomon's period (and probably belong to Ahab's time) -yet, on p. 53 (and including ' $\mathrm{IX}, 5^{\mathrm{I}}$ ' in n.3), he still implicitly attributes those same stables to Solomon, ignoring the contrary facts presented by Yadin!

\section{IN GONGLUSION}

We would make a plea for a factual presentation of this period of Old Testament history. This should commence with a statement that our sole record of the patriarchs and premonarchic Israel is that found in the pages of the Old Testament, with the one very limited exception of the mention of Israel as a people on Merenptah's well-known stela. Reference to the nature of the Hebrew records as interpreted by literary criticism, fairly stated as theoretical, might follow, with elaboration of the theory, and alternatives, appropriately indicated.

An outline of the basic content of the internal evidence would form a major section (Genesis 12-50 for the patriarchs), together with a clear, concise, comprehensive survey of the most relevant external data, pointing out both the specific value and the limitations of each main item in the dossier. After this a summary of the real truth about the patriarchs as far as can be known at present would clarify the situation; thus: they are individuals, their lives and circumstances frequently echo conditions attested in external sources (especially for the first half of the second millennium BC); absolute proof of their real existence is totally lacking, but it is a reasonable hypothesis to conclude provisionally that they probably did really once live in the kind of world in which Genesis and the external data agree in placing them. 
For later periods, the nature of the Old Testament data as sole record should again be noted (as Eissfeldt has done). Subject to this proviso, there is no warrant to do other than adopt the main outline of the Exodus-Deuteronomy traditions, of an exodus by a mixed body of people (including descendants of the old Hebrew family of Jacob, real or soi-disant) from the E. Delta in the thirteenth century BC; their covenant and sojourn in and around Sinai; their eventual conquest of parts of Transjordan and penetration of W. Palestine, at first superficially successful under one leader, and subsequently more slowly and patchily in tribal undertakings. Close attention to the biblical data would rule out a false contrast between the supposed total conquest unjustly attributed to the Book of Joshua (note Jos. 1 3:I-6) and the humbler struggles recorded in Judges-even the supposed late source ' $\mathrm{P}$ ' is widely recognized as containing ancient data. Then could follow Eissfeldt's paragraphs on Israel and Canaan, Saul, David and Solomon, with much less modification.

Professor Eissfeldt's erudition is well known and widely appreciated $; 85$ these fascicules present a difficult and intricate subject in a pleasantly clear and readable form. It is a matter for genuine and sympathetic sorrow that that erudition and clear style has been dissipated so largely in barren speculations of a kind in mode perhaps some sixty or seventy years ago, instead of being applied within the generally acknowledged realm of proper historical method in the full and up-to-date context of the relevant data of the Ancient Near East.

85. The present writer thinks with special pleasure and gratitude of (e.g.) Professor Eissfeldt's contributions in the Ugaritic field.

C) I966 K. A. KITCHEN

D 